Puspita, et al/Jurnal Ekonomi Syariah Teori dan Terapan Vol. 6 No. 5 Mei 2019: 913-927; IDENTIFIKASI PENYEBAB TIDAK OPTIMALNYA PENANGANAN PEMBIAYAAN BERMASALAH DI KSPS BMT ABC CABANG PEMBANTU KLM-SURABAYA

\title{
IDENTIFIKASI PENYEBAB TIDAK OPTIMALNYA PENANGANAN PEMBIAYAAN BERMASALAH DI KSPS BMT ABC CABANG PEMBANTU KLM-SURABAYA ${ }^{1}$
}

\author{
Martha Dyah Puspita \\ Departemen Ekonomi Syariah-Fakultas Ekonomi dan Bisnis-Universitas Airlangga \\ Email: Marthadepe@gmail.com \\ Dian Filianti \\ Departemen Ekonomi Syariah-Fakultas Ekonomi dan Bisnis-Universitas Airlangga \\ Email: dian.filianti@gmail.com
}

\begin{abstract}
:
Sharia Financial Services Cooperative (KJKS) is a form of cooperative whose business activities are engaged in financing, investment, and deposits in accordance sharia principles. in relation to financial services in the form of such financing, in this case the Sharia Financial Services Cooperative (KJKS) will be faced with several risks, among others, is the risk of default on financing channeled and the existence of fraud action (fraud) committedby the management of the financial institution. The object of this research is KSPS BMT ABC Branch KLM-Surabaya.on the object of the study found that the total gross NPF until December 2016 reached $81.84 \%$, in addition to the impact of high levels of Gross NPF is a loss to be borne until December 2016 amounted to Rp 354.715.664. Based on the results of preresearch interview with Mr. Muhammad stated that the cause of the loss due to there are two factors namely the existence of fraud (misconduct) in the form of misuse of funds by former employees and handling financing problems that can be optimally $30 \%$ of total troubled financing. The purpose of this study is to determine the cause of the non-optimal handling of troubled financing. Things that need to be reviewed in the process of handling pembiyaan problem is based on the phenomenon that occurs in the object of research. This research uses qualitative method with exploratory case study strategy. The results of research conducted by the researchers found that KSPS BMT ABC Branch KLM-Surabaya Assistant has a concept of mixing handling of non-performing financing based on standard operating procedures with the handling of troubled financing based on kinship.
\end{abstract}

Keywords: Troubled Financing, Troubled Financing Handling, Fraud

\section{PENDAHULUAN}

Pada dasarnya Koperasi Jasa Keuangan Syariah (KJKS) dapat tumbuh dan berkembang dengan baik atas dasar kepercayaan anggota serta masyarakat sekitar, salah satu dari 100 Koperasi Jasa Kevangan Syariah (KJKS) terbesar di Indonesia menurut majalah Peluang pada tahun 2012 ialah KSPS BMT ABC.

Koperasi ini dipelopori oleh adanya koperasi pertama yang didirikan oleh pondok pesentren $\mathrm{X}$ yakni koperasi BMT
$X Y Z$. Setelah koperasi BMT XYZ berjalan selama dua tahun maka banyak masyarakat Madrasah diniyah yang mendapat bantuan guru dari Pondok Pesantren X. Melalui urusan guru tugas, hal ini yang mendesak dan mendorong didirikan koperasi dengan skop yang lebih luas yakni skop Koperasi Jawa Timur. Faktor lain yang dapat mendorong berdirinya koperasi ialah para alumni Pondok Pesantren $X$ yang berdomisili di luar Kabupaten Pasuruan, maka pada

\footnotetext{
${ }^{1}$ Jurnal ini merupakan bagian dari skripsi Martha Dyah Puspita, NIM: 041411431049 , yang diuji pada tanggal 21 Maret 2018.
} 
Puspita, et al/Jurnal Ekonomi Syariah Teori dan Terapan Vol. 6 No. 5 Mei 2019: 913-927; IDENTIFIKASI PENYEBAB TIDAK OPTIMALNYA PENANGANAN PEMBIAYAAN BERMASALAH DI KSPS BMT ABC CABANG PEMBANTU KLM-SURABAYA

tanggal 05 Rabiul Awal 1421 Hijriyah atau 22 Juni 2000 Masehi diresmikan dan dibuka satu unit Koperasi BMT $A B C$ di Jalan Asem Mulyo 48 C Surabaya.

BMT ABC mendapatkan Badan Hukum Koperasi dari Kantor Wilayah Dinas Koperasi pengusaha Kecil dan Menengah Propinsi Jawa Timur dengan Surat Keputusan No: 09/BH/KWK/13/VII/2000, tertanggal 22 Juli 2000 dengan nama Koperasi $A B C$. Dengan mayoritas anggota guru tugas, namun seiring perkembangan lembaga keuangan berbasis syariah, fungsi koperasi tidak hanya ditujukan untuk guru tugas pondok pesantren X saja, akan tetapi juga ditujukan untuk masyarakat luas yang membutuhkan pelayanan koperasi jasa keuangan syariah.

Setelah sukses dengan kantor pusat serta cabang-cabang lain yang lebih dahulu hadir di masyarakat, maka salah seorang alumni Pondok Pesantren $\mathrm{X}$ berinisiatif untuk membuka kantor cabang pembantu yang baru di daerah Surabaya. Pembukaan kantor Cabang Pembantu ini dilatarbelakangi oleh keprihatinan alumni Pondok Pesantren terhadap praktek rentenir yang ada di pasar. Oleh sebab itu pada tanggal 26 Juni 2011, disetujuilah operasional KSPS BMT UGT ABC Cabang Pembantu KLMSurabaya oleh Dinas Koperasi serta pada tanggal itu pula dijadikan sebagai tanggal berdirinya KSPS BMT UGT ABC Cabang Pembantu KLM-Surabaya.
Dalam menjalankan kegiatan operasional nya KSPS BMT ABC Cabang Pembantu KLM-Surabaya berada dibawah pengawasan KSPS BMT $A B C$ Cabang Sidodadi-Surabaya, fungsi pengawasan yang dilakUkan oleh KSPS BMT ABC Cabang Sidodadi-Surabaya berupa konsultasi permasalahan pembiayaan maupun penghimpunan dana dari anggota, serta melakukan pengawasan kegiatan operasional KSPS BMT ABC Cabang Pembantu KLMSurabaya berdasarkan standar operasional prosedur cabang pembantu dari KSPS BMT ABC pusat.

Adapun peranan KSPS BMT ABC Cabang Pembantu KLM-Surabaya dalam memperkecil ketergantungan masyarakat sekitar terhadap keberadaan para rentenir dapat dibuktikan melalui jumlah pembiayaan yang telah disalurkan oleh KSPS BMT ABC Cabang Pembantu KLMSurabaya pada tahun 2016 mencapai Rp $7,436,653,600$ dari total pembiayaan yang diberikan kepada masyarakat.

Dalam menyalurkan pembiayaan, hal yang perlu diwaspadai oleh KSPS BMT ABC Cabang Pembantu KLM-Surabaya ialah tingkat Non Performing Financing (NPF) bruto yang cenderung mengalami kenaikan sejak bulan April hingga Desember 2016. NPF Bruto adalah prosentase jumlah pembiayaan yang dikategorikan dalam pembiayaan kurang lancar, diragukan dan macet dibanding dengan total pembiayaan yang disalurkan (sumber: buku pedoman Rapat 
Puspita, et al/Jurnal Ekonomi Syariah Teori dan Terapan Vol. 6 No. 5 Mei 2019: 913-927; IDENTIFIKASI PENYEBAB TIDAK OPTIMALNYA PENANGANAN PEMBIAYAAN BERMASALAH DI KSPS BMT ABC CABANG PEMBANTU KLM-SURABAYA

Anggota Tahunan KSPS BMT ABC tahun 2016).

Tabel 1.

Prosentase NPF Bruto KSPS BMT ABC

Cabang Pembantu KLM-Surabaya Tahun 2016

\begin{tabular}{|c|c|c|}
\hline Bulan & $\begin{array}{c}\text { Prosentas } \\
\text { e NPF }\end{array}$ & $\begin{array}{l}\text { Jumlah } \\
\text { Nasabah } \\
\text { Bermasala } \\
\text { h }\end{array}$ \\
\hline Januari & $27.33 \%$ & 199 Orang \\
\hline Februari & $15.75 \%$ & 202 Orang \\
\hline Maret & $8.12 \%$ & 172 Orang \\
\hline April & $11.04 \%$ & 201 Orang \\
\hline Mei & $11.34 \%$ & 208 Orang \\
\hline Juni & $12.37 \%$ & 212 Orang \\
\hline Juli & $19.75 \%$ & 234 Orang \\
\hline Agustus & $47.92 \%$ & 280 Orang \\
\hline $\begin{array}{c}\text { Septembe } \\
r\end{array}$ & $60.44 \%$ & 259 Orang \\
\hline Oktober & $80.60 \%$ & 276 Orang \\
\hline November & $81.30 \%$ & 271 Orang \\
\hline Desember & $81.84 \%$ & 280 Orang \\
\hline
\end{tabular}

Sumber: Laporan Keuangan dan Rekap NPF Bruto KSPS BMT ABC Cabang Pembantu KLM - Surabaya Tahun 2016

Dari data tingkat NPF Bruto KSPS BMT ABC Cabang Pembantu KLMSurabaya tersebut, dapat mencerminkan bahwa besaran kolektibilitas pembiayaan yang dikatagorikan dalam pembiayaan bermasalah cenderung mengalami kenaikan sejak bulan April hingga Desember 2016, selain itu dampak dari tingginya tingkat NPF Bruto adalah kerugian yang harus ditanggung oleh KSPS BMT ABC Cabang Pembantu KLMSurabaya hingga bulan Desember 2016 sebesar Rp 354.715.664 (Sumber: Laporan Laba Rugi KSPS BMT ABC Cabang Pembantu KLM-Surabaya Bulan Desember 2016).

Berdasarkan hasil wawancara pra penelitian dengan bapak Muhammad selaku pengawas kegiatan operasional KSPS BMT ABC Cabang Pembantu KLMSurabaya, upaya untuk mengendalikan kerugian akibat terjadinya pembiayaan bermasalah, KSPS BMT ABC Cabang Pembantu KLM-Surabaya telah melakukan penanganan atas pembiayaan bermasalah, akan tetapi, yang menyebabkan jumlah kerugiannya besar dikarenakan terdapat 2 faktor yakni adanya fraud (perbuatan menyimpang) berupa penyalahgunaan dana oleh mantan karyawan, serta keberhasilan dari penanganan pembiayaan bermasalah tersebut hingga desember 2016 hanya sebesar $30 \%$ saja dari total pembiayaan bermasalah yang dapat ditangani dengan optimal.

Oleh karena itu, untuk dapat mengendalikan kerugian secara optimal, perlu adanya upaya penanganan pembiayaan bermasalah yang baik dan tepat.

\section{Rumusan Masalah}

Berdasarkan uraian latar belakang diatas, maka rumusan masalah dalam penelitian ini adalah Bagaimana proses penanganan pembiayaan bermasalah yang telah dilakukan oleh KSPS BMT $A B C$ Cabang Pembantu KLM-Surabaya? 
Puspita, et al/Jurnal Ekonomi Syariah Teori dan Terapan Vol. 6 No. 5 Mei 2019: 913-927; IDENTIFIKASI PENYEBAB TIDAK OPTIMALNYA PENANGANAN PEMBIAYAAN BERMASALAH DI KSPS BMT ABC CABANG PEMBANTU KLM-SURABAYA

\section{Tujuan Penelitian}

Sesuai dengan rumusan masalah diatas, maka tujuan dari penelitian ini adalah mengidentifikasi dan menguraikan penyebab tidak optimalnya penanganan pembiayaan bermasalah serta menguraikan proses penanganan pembiayaan bermasalah yang telah dilakukan oleh KSPS BMT ABC Cabang Pembantu KLM-Surabaya.

\section{LANDASAN TEORI}

\section{Koperasi Syariah}

Istilah koperasi berasal dari kata (co $=$ bersama, operation $=$ usaha $)$ yang secara bahasa berarti bekerja bersama dengan orang lain untuk mencapai tujuan tertentu (Baharudin, 2013:1).

Menurut Mahmud Syaltut, koperasi (syirka ta'awuniyah) adalah suatu bentuk syirka baru yang belum dikenal oleh fuqaha terdahulu. Dilihat dari kewajiban penyertaan modal bagi tiap tiap anggota, disertai adanya pengangkatan sebagian anggota sebagai pengurus, menunjukan bahwa koperasi identik dengan akad syirka (kerjasama).

Persekutuan adalah salah satu bentuk kerjasama yang dianjurkan syara' karena dengan persekutuan berarti ada (terdapat) kesatuan, denganadanya kesatuan akan tercipta sebuah kekuatan, sehingga hendaknya kekuatan ini digunakan untuk menegakkan sesuatu yang benar menurut syara' (Suhendi, 2002:295).

\section{Koperasi Jasa Kevangan Syariah}

Koperasi Jasa Keuangan Syariah (KJKS) adalah Koperasi yang kegiatan usahanya bergerak dibidang pembiayaan, investasi, dan simpanan sesuai pola bagi hasil (syariah). Pengelolaan koperasi jasa keuangan syariah dilakukan oleh pengurus yang bertanggung jawab kepada rapat anggota. Apabila pengurus koperasi jasa kevangan syariah tersebut diserahkan kepada pengelola yang ditunjuk pengurus menjalankan tugas perencanaan kebijakan strategis, pengawasan dan pengendalian (Baharudin, 2013:139).

\section{Kolektibilitas Pembiayaan}

Menurut Baharudin, kolektibitas pembiayaan dalan Koperasi Jasa Kevangan Syariah (KJKS) digolongkan dalam 4 macam yakni (Baharudin, 2013:313):

1. Pembiayaan Lancar

a. Akad Murabahah, Salam, Istishna, Qardh, ljarah, ljarah Muntahiya Bittamlik dan Traksaksi Multijasa.

Pembiayaan untuk akad tersebut dikatakan lancar jika masa angsuran bulanan (angsuran pokok dan atau margin/fee) tidak terjadi tunggakan angsuran sampai dengan 3 bulan dan pembiayaan belum jatuh tempo.

b. Akad Mudharabah dan Musyarakah Pembiayaan untuk akad tersebut dikatakan lancar jika pembayaran pokok dan perlunasan pokok tepat waktu, atau pembayaran (bagi 
hasil) dimana rencana pendapatan (RP) sama atau lebih dari $80 \%$ penerimaan pendapatan (PP)

2. Pembiayaan Kurang Lancar

a. Akad Murabahah, Salam, Istishna, Qardh, ljarah, ljarah Muntahiya Bittamlik dan Traksaksi Multijasa.

1) Akad pembayaran bulanan Pembiayaan pada akad tersebut dikatakan kurang lancar jika masa angsuran bulanan langsuran pokok dana tau margin/fee) terdapat tunggakan angsuran yang telah melewati 3 bulan sampai dengan 6 bulan, atau pembiayaan telah jatuh tempo dari 1 bulan (angsuran pokok dana tau margin/fee) terdapat tunggakan 3 bulan.

2) Akad pembayaran mingguan Pembiayaan pada akad tersebut dikatakan kurang lancar jika masa angsuran mingguan langsuran pokok dan atau margin/fee) terdapat tunggakan angsuran yang telah melewati 3 minggu sampai dengan 6 minggu, atau pembiayaan telah jatuh tempo dari 1 minggu langsuran pokok dan atau margin/fee) terdapat tunggakan 3 minggu.

3) Akad pembayaran harian Pembiayaan pada akad tersebut dikatakan kurang lancar jika masa angsuran harian (angsuran pokok dan atau margin/fee) terdapat tunggakan angsuran yang telah melewati 3 hari sampai dengan 6 hari, atau pembiayaan telah jatuh tempo dari 1 hari (angsuran pokok dan atau margin/fee) terdapat tunggakan 3 hari.

b. Akad Mudharabah dan Musyarakah

1) Akad pembayaran bulanan Pembiayaan untuk akad tersebut dikatakan kurang lancar jika pembayaran pokok dan perlunasan pokok terdapat tunggakan 3 (bulan), atau pembayaran (bagi hasil) dimana rencana pendapatan (RP) diatas $30 \%$ sampai dengan $80 \%$ penerimaan pendapatan (PP)

2) Akad pembayaran mingguan Pembiayaan untuk akad tersebut dikatakan kurang lancar jika pembayaran pokok dan perlunasan pokok terdapat tunggakan 3 (minggu), atau pembayaran (bagi hasil) dimana rencana pendapatan (RP) diatas $30 \%$ sampai dengan $80 \%$ penerimaan pendapatan (PP)

3) Akad pembayaran harian Pembiayaan untuk akad tersebut dikatakan kurang lancar jika pembayaran pokok dan perlunasan pokok terdapat tunggakan 3 (hari), atau pembayaran (bagi hasil) dimana rencana pendapatan (RP) diatas 
Puspita, et al/Jurnal Ekonomi Syariah Teori dan Terapan Vol. 6 No. 5 Mei 2019: 913-927; IDENTIFIKASI PENYEBAB TIDAK OPTIMALNYA PENANGANAN PEMBIAYAAN BERMASALAH DI KSPS BMT ABC CABANG PEMBANTU KLM-SURABAYA

$30 \%$ sampai dengan $80 \%$ penerimaan pendapatan (PP)

3. Pembiayaan Diragukan

a. Akad Murabahah, Salam, Istishna, Qardh, ljarah, ljarah Muntahiya Bittamlik dan Traksaksi Multijasa.

1) Akad pembiayaan bulanan

Pembiayaan pada akad tersebut dikatakan diragukan jika masa angsuran bulanan langsuran pokok dan atau margin/fee) terdapat tunggakan angsuran yang telah melewati 6 bulan sampai dengan 12 bulan, atau pembiayaan jatuh tempo telah melewati 1 bulan sampai dengan 2 bulan.

2) Akad pembiayaan mingguan Pembiayaan pada akad tersebut dikatakan diragukan jika masa angsuran mingguan (angsuran pokok dan atau margin/fee) terdapat tunggakan angsuran yang telah melewati 6 minggu sampai dengan 12 minggu, atau pembiayaan jatuh tempo telah melewati 1 minggu sampai 2 minggu,

3) Akad pembiayaan harian

Pembiayaan pada akad tersebut dikatakan diragukan jika masa angsuran harian (angsuran pokok dan atau margin/fee) terdapat tunggakan angsuran yang telah melewati 6 hari sampai dengan 12 hari, atau pembiayaan jatuh tempo telah melewati 1 hari sampai 2 hari.

b. Akad Mudharabah dan Musyarakah

1) Akad pembayaran bulanan

Pembiayaan untuk akad tersebut

dikatakan diragukan jika

pembayaran pokok dan

perlunasan pokok terdapat

tunggakan 3 (bulan) sampai dengan 24 (bulan).

2) Akad pembayaran mingguan

Pembiayaan untuk akad tersebut dikatakan diragukan jika pembayaran pokok dan perlunasan pokok terdapat tunggakan 3 (minggu) sampai dengan 24 (minggu).

3) Akad pembayaran harian Pembiayaan untuk akad tersebut dikatakan diragukan jika pembayaran pokok dan perlunasan pokok terdapat tunggakan 3 (hari) sampai dengan 24 (hari).

4. Pembiayaan Macet

a. Akad Murabahah, Salam, Istishna, Qardh, ljarah, ljarah Muntahiya Bittamlik dan Traksaksi Multijasa.

1) Akad pembayaran bulanan Pembiayaan untuk akad tersebut dikatakan macet jika masa angsuran bulanan (angsuran pokok dan atau margin/fee) terdapat tunggakan angsuran yang telah melewati 12 bulan, atau pembiayaan jatuh tempo telah melewati 2 bulan, atau 
Puspita, et al/Jurnal Ekonomi Syariah Teori dan Terapan Vol. 6 No. 5 Mei 2019: 913-927; IDENTIFIKASI PENYEBAB TIDAK OPTIMALNYA PENANGANAN PEMBIAYAAN BERMASALAH DI KSPS BMT ABC CABANG PEMBANTU KLM-SURABAYA

telah diserahkan kepada pengadilan negeri (PN) atau BPUN, atau telah diajukan penggantian ganti rugi kepada perusahaan asuransi kredit / pembiayaan.

2) Akad pembayaran mingguan

Pembiayaan untuk akad tersebut dikatakan macet jika masa angsuran mingguan (angsuran pokok dan atau margin/fee) terdapat tunggakan angsuran yang telah melewati 12 minggu, atau pembiayaan jatuh tempo telah melewati 2 minggu, atau telah diserahkan kepada pengadilan negeri (PN) atau BPUN, atau telah diajukan penggantian ganti rugi kepada perusahaan asuransi kredit atau pembiayaan.

3) Akad pembayaran harian

Pembiayaan untuk akad tersebut dikatakan macet jika masa angsuran harian (angsuran pokok dan atau margin/fee) terdapat tunggakan angsuran yang telah melewati 12 hari, atau pembiayaan jatuh tempo telah melewati 2 hari, atau telah diserahkan kepada pengadilan negeri (PN) atau BPUN, atau telah diajukan penggantian ganti rugi kepada perusahaan asuransi kredit atau pembiayaan.

b. Akad Mudharabah dan Musyarakah 1) Akad pembayaran bulanan
Pembiayaan untuk akad tersebut

dikatakan macet jika

pembayaran pokok dan perlunasan pokok terdapat tunggakan melampaui 24 (bulan) atau pembayaran (bagi hasil) dimana rencana pendapatan (RP) kurang dari 30\%, penerimaan pendapatan (PP) lebih dari 3 periode pembayaran.

2) Akad pembayaran mingguan Pembiayaan untuk akad tersebut dikatakan macet jika pembayaran pokok dan perlunasan pokok terdapat tunggakan melampaui 24 (minggu) atau pembayaran (bagi hasil) dimana rencana pendapatan (RP) kurang dari $30 \%$, penerimaan pendapatan (PP) lebih dari 3 periode pembayaran.

3) Akad pembayaran harian Pembiayaan untuk akad tersebut dikatakan macet jika pembayaran pokok dan perlunasan pokok terdapat tunggakan melampavi 24 (hari) atau pembayaran (bagi hasil) dimana rencana pendapatan (RP) kurang dari $30 \%$, penerimaan pendapatan (PP) lebih dari 3 periode pembayaran.

\section{Pembiayaan Bermasalah}

Pembiayaan bermasalah adalah suatu kondisi pembiayaan dimana terdapat suatu penyimpangan utama 
Puspita, et al/Jurnal Ekonomi Syariah Teori dan Terapan Vol. 6 No. 5 Mei 2019: 913-927; IDENTIFIKASI PENYEBAB TIDAK OPTIMALNYA PENANGANAN PEMBIAYAAN BERMASALAH DI KSPS BMT ABC CABANG PEMBANTU KLM-SURABAYA

dalam pembayaran kembali pembiayaan yang berakibat terjadi keterlambatan dalam pengembalian, atau diperlukan tindakan yuridis dalam pengembalian atau kemungkinan terjadinya kerugian bagi koperasi (Baharudin, 2013: 251)

\section{Teknik penyelamatan Pembiayaan Bermasalah}

Penyelamatan pembiayaan bermasalah bersifat kasuistis, artinya setiap usaha debitur memiliki permasalahan yang berbeda satu sama lain, sehingga pembiayaan bermasalah yang akan diselamatkan juga menggunakan strategi yang berbeda. Namun, secara umum dapat disebutkan bahwa strategi penyelamatan pembiayaan bermasalah dapat berupa rescheduling (penjadwalan kembali), reconditioning (persyaratan kembali), dan restructuring (penataan kembali) (Subagyo, 2015:85)

Menurut Triandini (2006) adapun landasan syariah yang mendukung upaya restrukturisasi pembiayaan terdapat pada surat Al-Baqarah ayat 280 :

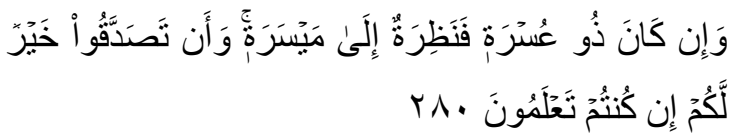

Wa In Kāna Żu 'Usratin Fa Nażiratun IIā Maisarah, Wa An Tașaddaqu Khairul Lakum Ing Kuntum Ta'lamụn.

Artinya: Dan jika lorang yang berhutang itu) dalam kesulitan, maka berilah tenggang waktu sampai dia memperoleh kelapangan. Dan jika kamu menyedekahkan, itu lebih baik bagimu, jika kamu mengetahui (Trisandini, 2006).
Tafsir dari ayat diatas menurut $M$. Quraisy Shihab (2002:727) adalah apabila ada seseorang yang berada dalam situasi sulit, atau akan terjerumus dalam kesulitan bila membayar utangnya, tangguhkanlah penagihan sampai dia lapang. Jangan menagihnya jika kamu mengetahui dia sempit, apalagi memaksanya membayar dengan sesuatu yang amat dia butuhkan.

\section{Teknik penyelesaian Pembiayaan Bermasalah}

Menurut Ahmad Subagyo, teknik penyelesaian pembiayaan dapat dilakukan melalui 2 cara yakni upaya penyelesaian diluar proses pengadilan dan upaya penyelesaian dengan proses pengadian (Subagyo, 2015:99).

\section{METODE PENELITIAN}

\section{Pendekatan penelitian}

Pendekatan yang digunakan pada penelitian ini adalah pendekatan kualitatif

\section{Unit Analisis}

Menurut Yin (2015:30) unit analisis merupakan komponen yang berkaitan dengan "kasus" dalam suatu penelitian. Unit analisis dalam penelitian ini terdiri dari Identifikasi penyebab penanganan pembiayaan bermasalah tidak optimal, Revitalisasi, Collection agent, Penyelesaian melalui jaminan dan Write off final.

\section{Ruang Lingkup Penelitian}

Pembiayaan bermasalah yang dimaksud dalam penelitian ini adalah pembiayaan dengan kolektabilitas 
Puspita, et al/Jurnal Ekonomi Syariah Teori dan Terapan Vol. 6 No. 5 Mei 2019: 913-927; IDENTIFIKASI PENYEBAB TIDAK OPTIMALNYA PENANGANAN PEMBIAYAAN BERMASALAH DI KSPS BMT ABC CABANG PEMBANTU KLM-SURABAYA

pembiayaan kurang lancar, diragukan dan macet.

\section{Jenis dan Sumber Data}

Jenis data yang digunakan dalam penelitian ini terdiri atas data primer dan data sekunder. Data primer diperoleh dari wawancara dengan kepala cabang pembantu KLM, account officer analisa dan penagihan pembiayaan cabang pembantu KLM, kepala bagian legal dan remidial Cabang Sidodadi serta kepala Cabang Sidodadi.

Data sekunder dalam penelitian ini diperoleh dari buku, jurnal, majalah, surat kabar, dan dokumen atau laporan kegiatan penelitian yang pernah dilakukan yang terkait dengan penanganan pembiayaan bermasalah pada KSPS BMT ABC Cabang Pembantu KLM-Surabaya.

\section{Prosedur Pengumpulan Data}

a. Persiapan Awal, Mengidentifikasi rumusan masalah serta tujuan penelitianserta mengurus surat oengantar penelitian dari Fakultas Ekonomi dan Bisnis

b. Penelitian Lapangan, melakukan pengambilan data melalui wawancara, pengumpulan dokumen serta melakukan kajian pustaka dan literatur

\section{Teknik Keabsahan Data}

Dalam peneltian ini triangulasi sumber data dilakukan dengan cara membandingkan hasil wawancara dengan isi suatu dokumen yang berkaitan guna memperoleh keterkaitan antar data, sedangkan triangulasi metode dilakukan dengan cara membandingkan hasil wawancara dari satu informan dengan informan yang lainnya.

\section{Teknik Analisis Data}

Teknik analisis yang digunakan dalam penelitian ini menggunakan teknik analisis data, menurut Miles and Huberman dalam buku Sugiyono (2012:247), yang menjelaskan ada tiga proses yaitu:

a. Reduksi Data

b. Penyajian Data

c. Penarikan Kesimpulan

\section{HASIL DAN PEMBAHASAN}

\section{Hasil Identifikasi Penyebab Kerugian}

Berdasarkan hasil penelitian dilapangan ditemukan bahwa penyebab adanya kerugian pada KSPS BMT $A B C$ Cabang Pembantu KLM-Surabaya terjadi karena disebabkan oleh adanya tindakan fraud yang dilakukan oleh mantan karyawan KSPS BMT ABC Cabang Pembantu KLM-Surabaya.

Tindakan fraud tersebut berakibat pada penanganan pembiayaan bermasalah pada KSPS BMT ABC Cabang Pembantu KLM-Surabaya menjadi tidak optimal. Hal ini dapat terjadi dikarenakan adanya 3 faktor yaitu sebagai berikut:

1. Tindakan memanipulasi data yang dilakukan oleh oknum fraud.

2. Tidak adanya analisa kelayakan pembiayaan yang sesuai dengan prosedur pembiayaan, dan hal tersebut juga dapat mengakibatkan 
Puspita, et al/Jurnal Ekonomi Syariah Teori dan Terapan Vol. 6 No. 5 Mei 2019: 913-927; IDENTIFIKASI PENYEBAB TIDAK OPTIMALNYA PENANGANAN PEMBIAYAAN BERMASALAH DI KSPS BMT ABC CABANG PEMBANTU KLM-SURABAYA

adanya indikasi pembiayaan fiktif yang dilakukan oleh oknum fraud tersebut.

3. Oknum fraud tidak melaksanakan serah terima wewenang atau tanggung jawab mengenai penanganan pembiayaan bermasalah kepada karyawan baru yang menggantikan jabatannya.

Selain itu terdapat 2 faktor lain yang menjadi penghambat dalam proses penanganan pembiayaan bermasalah yakni sebagai berikut:

1. Belum terdapat Standar Operasional Prosedur terkait pengikatan jaminan secara hukum, pada januari hingga Juni tahun 2016. Operasional Prosedur terkait pengikatan jaminan secara hukum ada dan efektif dilaksanakan pada Januari tahun 2017.

2. Tidak adanya tindakan pengawasan atas pembiayaan yang telah disalurkan kepada anggota pembiayaan dan hal tersebut mengakibatkan penanganan pembiayaan bermasalah menjadi sulit dikarenakan dana pembiayaan yang telah terealisasikan kepada anggota diperuntukan untuk hal hal yang tidak sesuai dengan akad pembiayaan.

\section{Hasil Penanganan pembiayaan} bermasalah Yang Telah Dilakukan

Berdasarkan hasil penelitian dilapangan ditemukan bahwa penanganan pembiyaan bermasalah yang telah dilakukan oleh KSPS BMT $A B C$ pusat dan cabang pembantu KLMSurabaya. Upaya yang telah dilakukan oleh KSSP BMT ABC Pusat adalah melakukan pemilahan data terkait dengan daftar anggota pembiayaan bermasalah KSPS BMT ABC Cabang Pembantu KLM-Surabaya. Adapun Upaya yang telah dilakukan oleh KSSP BMT ABC Cabang Pembantu KLM-Surabaya adalah

1. Melakukan kunjungan secara langsung kepada anggota pembiayaan bermasalah. $\mathrm{Hal}$ ini dilakukan guna membuktikan pembiayaan tersebut fiktif atau riil, serta kunjungan tersebut juga bertujuan untuk menganalisis penyebab anggota pemmbiayaan tersebut menjadi bermasalah.

2. Mencatat seluruh hasil analisa penyebab pembiayaan tersebut bermasalah pada berita acara penagihan (BAP).

3. Merestrukturisasi pembiayaan bermasalah berdasarkan asas kekeluargaan, sehingga untuk memperkecil nominal angsuran pembiayaan (Reschedulling) disesuaikan dengan kemampuan anggota pembiayaan bermasalah dan hal tersebut menyebabkan jangka waktu angsuran pembiayaan juga harus diperpanjang hingga pembiayaan tersebut lunas.

\section{Hasil Pencegahan Penanganan Pembiayaan bermasalah Yang Telah Dilakukan}

Berdasarkan hasil penelitian dilapangan ditemukan bahwa pencegahan pembiayaan bermasalah 
Puspita, et al/Jurnal Ekonomi Syariah Teori dan Terapan Vol. 6 No. 5 Mei 2019: 913-927; IDENTIFIKASI PENYEBAB TIDAK OPTIMALNYA PENANGANAN PEMBIAYAAN BERMASALAH DI KSPS BMT ABC CABANG PEMBANTU KLM-SURABAYA

telah dilakukan oleh KSPS BMT ABC cabang pembantu KLM-Surabaya adalah dengan mematuhi seluruh aturan Standart Operasional Prosedur dalam menjalankan kegiatan operasional, baik kegiatan operasional pembiayaan maupun kegiatan operasional penghimpunan dana penghimpunan dana.

\section{Pembahasan}

Dalam menangani pembiayaan bermasalah KSPS BMT ABC telah memiliki standar operasional prosedur No. LGR/SOP001/REV02 yang secara baku telah ditetapkan dan sosialisasikan kepada seluruh Account Officer Analisa dan Pembiayaan (AOAP) cabang maupun cabang pembantu dengan tujuan untuk dapat meminimalisir kerugian yang timbul sebagai dampak dari adanya pembiayaan bermasalah.

Namun berdasarkan studi lapangan yang telah dilakukan menegaskan bahwa standar operasional prosedur No. LGR/SOP001/REV02 yang telah ada apabila diterapkan pada penanganan pembiayaan bermasalah yang terjadi, menurut bapak riyal dan bapak Baihaqi selaku Account Officer Analisa dan Pembiayaan (AOAP) selama ini dinilai terlampau ketat, sehingga apabila Account Officer Analisa dan Pembiayaan (AOAP) melakukan penanganan pembiayaan bermasalah sepenuhnya berdasarkan standar operasional prosedur No. LGR/SOP001/REV02 tentang penanganan pembiayaan bermasalah justru akan menyebabkan penanganan pembiayaan tersebut sulit diselesaikan dengan optimal sesuai dengan kemauan dan kemampuan anggota.

Sehingga untuk dapat mempermudah penanganan pembiayaan bermasalah, Account Officer Analisa dan Pembiayaan (AOAP) KSPS BMT ABC Cabang SidodadiSurabaya maupun KSPS BMT ABC Cabang Pembantu KLM-Surabaya mempunyai konsep perpaduan antara penanganan pembiayaan bermasalah berdasarkan standar operasional prosedur No. LGR/SOP001/REV02 dengan penanganan pembiayaan bermasalah berdasarkan kekeluargaan.

Adapun latar belakang yang menyebabkan Account Officer Analisa dan Pembiayaan (AOAP) KSPS BMT ABC Cabang Sidodadi-Surabaya maupun KSPS BMT ABC Cabang Pembantu KLMSurabaya memodifikasi konsep penanganan pembiayaan bermasalah adalah Account Officer Analisa dan Pembiayaan (AOAP) lebih berfokus pada penanganan pembiayaan tersebut didasarkan pada kemavan anggota untuk dapat melunasi segala kewajibannya, menurut bapak Riyal, apabila anggota pembiayaan bermasalah tersebut telah memiliki kemauan untuk melunasi seluruh kewajibannya kepada BMT, maka walaupun dari segi kemampuan anggota tersebut dinilai belum sepenuhnya mampu, namun anggota pembiayaan bermasalah tersebut akan tetap 
Puspita, et al/Jurnal Ekonomi Syariah Teori dan Terapan Vol. 6 No. 5 Mei 2019: 913-927; IDENTIFIKASI PENYEBAB TIDAK OPTIMALNYA PENANGANAN PEMBIAYAAN BERMASALAH DI KSPS BMT ABC CABANG PEMBANTU KLM-SURABAYA

mengupayakan membayar tunggakan angsuran yang menjadi kewajiban yang harus dilunasi oleh anggota tersebut kepada BMT.

Oleh karena itu untuk dapat meningkatkan kesadaran dan kemauan anggota pembiayaan bermasalah untuk melunasi seluruh kewajibannya kepada BMT, Account Officer Analisa dan Pembiayaan (AOAP) KSPS BMT ABC Cabang Sidodadi-Surabaya maupun KSPS BMT ABC Cabang Pembantu KLMSurabaya memodifikasi konsep penanganan pembiayaan bermasalah dengan menggabungkan konsep yang telah dijelaskan pada standar operasional prosedur No. LGR/SOP001/REV02 dengan konsep kekeluargaan.

Adapun prinsip kekeluargaan yang digunakan oleh Account Officer Analisa dan Pembiayaan (AOAP) KSPS BMT ABC Cabang Sidodadi-Surabaya maupun KSPS BMT ABC Cabang Pembantu KLMSurabaya guna meningkatkan kesadaran dan kemauan anggota untuk melunasi seluruh kewajibannya ialah sebagai berikut:

1. Konsep toleransi.

Berdasarkan studi lapangan yang telah dilakukan, menurut bapak Zainal menjelaskan bahwa walaupun anggota pembiayaan bermasalah tersebut sangat merugikan banyak pihak terkait dengan tunggakan angsuran yang belum terbayarkan, akan tetapi pihak KSPS BMT ABC Cabang Pembantu KLM-Surabaya tetap memberikan batas perpanjangan jangka waktu maksimal dalam perlunasan pembiyaan, hal ini dilakukan dengan tujuan apabila nasabah tersebut mengalami musibah atau sakit, sehingga berdampak pada keterlambatan membayar tunggakan angsuran.

2. Konsep tolong-menolong.

Berdasarkan studi lapangan yang telah dilakukan, menurut bapak Riyal menjelaskan bahwa dalam meningkatkan kesadaran dan kemavan anggota pembiayaan bermasalah untuk melunasi seluruh kewajiban nya kepada BMT, ialah dengan memberikan kemudahan kepada anggota pembiayaan bermasalah dan mempertimbangkan aspek sumber pendapatan yang dimiliki oleh anggota pembiayaan bermaslaah tersebut. Seperti yang terjadi pada suatu kasus pembiayaan bermasalah yang menyebabkan nasabah tersebut merasa tidak mampu untuk membayar sehingga menyerahkan motor sebagai agunan dalam pembiayaan tersebut untuk di eksekusi oleh BMT, akan tetapi bapak riyal menganjurkan nasabah tersebut untuk melunasi tunggakan angsuran pembiayaan anggota tersebut hingga lunas, dengan alasan apabila motor tersebut dieksekusi oleh BMT, maka anggota pembiayaan bermasalah tersebut tidak dapat bekerja dan menghidupi keluarganya.

Prinsip kekeluargaan yang telah dilakukan oleh Account Officer Analisa dan Pembiayaan (AOAP) tersebut telah dibenarkan secara teori dan praktek. 
Puspita, et al/Jurnal Ekonomi Syariah Teori dan Terapan Vol. 6 No. 5 Mei 2019: 913-927; IDENTIFIKASI PENYEBAB TIDAK OPTIMALNYA PENANGANAN PEMBIAYAAN BERMASALAH DI KSPS BMT ABC CABANG PEMBANTU KLM-SURABAYA

Menurut Ahmad Subagyo (2015:99), penyelesaian pembiayaan bermasalah dengan cara damai seringkali dapat membawa hasil yang lebih memuaskan diantara kedua belah pihak, oleh karena itu selama proses penyelesaian pembiayaan bermasalah seyogyanya pihak bank tetap memelihara hubungan baik dengan debitur. Salah satu bentuk jalan damai ialah mengijinkan pihak debitur menjual sendiri barang jaminannya, dengan begitu debitur akan menjual jaminannya dengan harga yang wajar, sehingga masih terdapat kemungkinan sisa hasil penjualan bagi debitur setelah semua kewajibannya terlunasi.

Selain itu menurut Kalyisah (2013) dalam penelitiannya pada BMT Al-Amin Makassar menyatakan bahwa, penerapan prinsip kekelvargaan yang tertuang pada prinsip persaudaraan, tolong menolong serta toleransi dalam menangangani pembiayaan bermasalah dapat memberikan dampak positif bagi BMT untuk dapat menyelesaikan pembiayaan bermasalah yang terjadi.

Latar belakang adanya modifikasi konsep penanganan pembiayaan bermasalah tersebut dikarenakan kondisi lapangan yang mengharuskan Account Officer Analisa dan Pembiayaan (AOAP) berfikir strategis dalam menagani pembiayaan bermasalah. Modifikasi konsep ini juga dapat menimbulkan konsekuensi bagi Account Officer Analisa dan Pembiayaan (AOAP), dikarenakan
Account Officer Analisa dan Pembiayaan (AOAP) tidak mematuhi dan menjalankan standar operasional prosedur No. LGR/SOP001/REV02 dengan baik dan benar. Sebagai konsekuensi dari hal tersebut maka sering kali Account Officer Analisa dan Pembiayaan (AOAP) harus menghadap kepada kepala cabang pembantu, kepala cabang ataupun pengawas, guna menjelaskaan terkait tindakan penaganan pembiayaan bermasalah yang tidak sesuai dengan standar operasional prosedur No. LGR/SOP001/REV02 dilatar belakangi oleh strategi yang harus dilakukan oleh Account Officer Analisa dan Pembiayaan (AOAP) adalah membangun kesadaran dan kemavan anggota pembiayaan bermasalah untuk melunasi seluruh kewajibannya kepada BMT.

Adapun serangkaian proses yang telah dilakukan dalam menangani pembiayaan bermasalah dengan menggunakan perpaduan konsep antara peraturan yang telah ada dalam standar operasional prosedur No. LGR/SOP001/REV02 dengan konsep kekeluargaan ialah sebagai berikut:

1. Melakukan kunjungan secara langsung kepada anggota bermasalah.

2. Mengidentifikasi penyebab pembiayaan tersebut menjadi bermasalah

3. Mencatat hasil identifikasi penyebab pembiayaan bermasalah dalam Berita Acara Penagihan (BAP). 
Puspita, et al/Jurnal Ekonomi Syariah Teori dan Terapan Vol. 6 No. 5 Mei 2019: 913-927; IDENTIFIKASI PENYEBAB TIDAK OPTIMALNYA PENANGANAN PEMBIAYAAN BERMASALAH DI KSPS BMT ABC CABANG PEMBANTU KLM-SURABAYA

4. Menganalisis solusi yang tepat untuk penanganan pembiayaan bermasalah berdasarkan kemampuan keuangan yang dimiliki oleh anggota pembiayaan bermasalah.

Berdasarkan pembahasan terkait modifikasi konsep penanganan pembiayaan bermasalah yang dilakukan oleh Account Officer Analisa dan Pembiayaan (AOAP) KSPS BMT ABC Cabang Sidodadi-Surabaya maupun KSPS BMT ABC Cabang Pembantu KLMSurabaya diatas menegaskan bahwa dengan menggunakan konsep kekelvargaan, akan memberikan peluang lebih banyak bagi anggota bermasalah untuk dapat merasa lebih nyaman dan dapat memenuhi kewajibannya dengan kemauan dan kesadaran. Sehingga langkah yang diambil oleh Account Officer Analisa dan Pembiayaan (AOAP) KSPS BMT ABC Cabang Sidodadi-Surabaya maupun KSPS BMT ABC Cabang Pembantu KLMSurabaya dalam mengoptimalkan hasil dari penanganan pembiayaan bermasalah ialah dengan menerapkan konsep kekeluargaan.

\section{SIMPULAN}

Account Officer Analisa dan Pembiayaan (AOAP) KSPS BMT ABC Cabang Sidodadi-Surabaya maupun KSPS BMT ABC Cabang Pembantu KLMSurabaya mempunyai konsep perpaduan antara penanganan pembiayaan bermasalah berdasarkan standar operasional prosedur dan penanganan pembiayaan bermasalah berdasarkan kekeluargaan. Konsep tersebut dilakukan karena akan memberikan peluang lebih banyak bagi anggota bermasalah untuk dapat merasa nyaman dan dapat memenuhi kewajibannya dengan kemauan dan kesadaran. Adapun serangkaian proses yang telah dilakukan dalam menangani pembiayaan bermasalah ialah sebagai berikut:

a. Melakukan kunjungan secara langsung kepada anggota bermasalah.

b. Mengidentifikasi penyebab pembiayaan tersebut menjadi bermasalah.

c. Mencatat hasil identifikasi penyebab pembiayaan bermasalah dalam Berita Acara Penagihan (zBAP).

d. Memusyawarahkan solusi penanganan pembiayaan bermasalah berdasarkan kondisi yang ada pada anggota pembiayaan bermasalah serta kemampuan anggota pembiayaan bermasalah.

\section{Saran}

1. Bagi KSPS BMT $A B C$.

KSPS BMT ABC hendaknya melakukan pengawasan pembiayaan yang telah tersalurkan kepada anggota, pengawasan pembiyaan tersebut dapat berfungsi untuk dapat mempermudah penanganan apabila pembiayaan tersebut bermasalah.

2. Bagi peneliti selanjutnya.

a. Bagi peneliti selanjutnya hendaknya meneliti dengan topik yang sama dengan objek penelitian lebih 
banyak lagi, karena kondisi Koperasi Syariah serta perilaku masyarakat tiap daerah berbeda-beda.

b. Bagi peneliti selanjutnya dapat meneliti mekanisme kerja tim sistem pengendali internal di KSPS BMT $A B C$.

\section{DAFTAR PUSTAKA}

Antonio, Muhammad Syafi'i. 2001. Bank syariah: Dari teori ke praktik. Jakarta.

Baharuddin, Kalyisah. 2013. Penerapan Prinsip Kekelvargaan Dalam Penyelesaian Pembiayaan Bermasalah Pada BMT Al-Amin Makasar. Skripsi. Makasar: Fakultas Ekonomi Dan Bisnis Universitas Hasanudin.

Baharudin, S. 2013. Koperasi Syariah dan Pengaturanya di Indonesia.

Karim A, Adiwarman. 2014. Bank Islam: analisis fiqih dan keuangan. Jakarta.

KSPS BMT ABC. 2017. Pedoman Rapat Anggota Tahunan KSPS BMT ABC tahun 2016. Pasuruan.

Moleong, lexy J. 2009. Metode penelitian kualitatif. Bandung.

Shihab M Quraish. 2002. Tafsir Al - Misbah, Jakarta.

Subagyo, Ahmad. 2015. Manajemen Operasi Lembaga Keuangan Mikro Syariah. Jakarta.

Subagyo, Ahmad. 2015. Teknik Penyelesaian Kredit Bermasalah. Jakarta.
Sugiyono, Prof. Dr. 2009. Metode penelitian kuantitatif, kualitatif, dan R\&D. Bandung.

Suhendi, Hendi. 2002. Figh Muamalah, edisi 9. Jakarta.

Usanti, Trisandini P. 2006. Restrukturisasi Pembiayaan Sebagai Salah Satu Upaya Penanganan Pembiayaan Bermasalah. Vol IX, No III.

Usanti, Trisandini P dan Abd Shomad. 2015. Transaksi Bank Syariah. Jakarta: Bumi Aksara

Yin, Robert K. 2015. Studi Kasus Design \& Metode. Jakarta: Raja Grafindo Persada 